\title{
Comparison of the bread-making performance of spelt varieties grown under organic conditions in the environment of northern Serbia and their responses to dough strengthening improvers
}

\author{
Bojana Filipčev ${ }^{1}$, Olivera Šimurina ${ }^{1}$, Marija Bodroža-Solarov ${ }^{1}$, Dragana Obreht ${ }^{2}$ \\ ${ }^{1}$ University of Novi Sad, Institute of Food Technology, Novi Sad, Serbia \\ ${ }^{2}$ University of Novi Sad, Faculty of Sciences, Department of Biology and Ecology, Novi Sad, Serbia
}

\begin{abstract}
Spelt varieties were tested in 2010 and 2011 for dough rheology, bread-making and allelic gene composition coding for HMW glutenin subunits in order to evaluate the baseline of their baking potential, as well as the suitability for their growth under organic conditions. The results showed that the tested genotypes had high protein and gluten contents, but varying gluten index exhibited moderate to poor rheological properties characterized with short dough stabilities. The spelt varieties showed typical bread yields, low specific volumes, and large variation in crumb firmness. Their bread-making potential was mostly associated with dough strength and tenacity. The majority of traits were significantly affected by genotype, year and their interaction. Genotype 1 and Genotype 3 showed moderate suitability for bread-making applications, whereas Genotype 2 had poor performance, which was in agreement with its genetic potential as determined by the allelic composition. Spelt Genotype 3 showed the highest response to the tested dough strengthening improvers (ascorbic acid, transglutaminase, and glucose oxidase). All the tested varieties were most responsive to the action of ascorbic acid.
\end{abstract}

Keywords: spelt, dough rheology, bread making, ascorbic acid, transglutaminase, glucose oxidase.

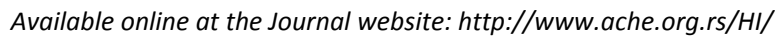

\section{SCIENTIFIC PAPER}

UDC 631.95(497.11-17)

633.11:575.22:664.6/7

Hem. Ind. 67 (3) 443-453 (2013)

doi: 10.2298/HEMIND120606083F
There has been an increasing interest in organic agricultural systems worldwide due to many advantages these systems may confer to consumers and the environment, which span from food free of harmful chemicals and increased biodiversity throughout the food-chain, to economical benefits of marginal areas suitable for organic production. Consequently, this has raised the importance of alternative cereals, which are naturally adapted for growth in low-input systems and thus have high ecological value. Spelt wheat is one such alternative crop suitable for organic farming.

Spelt wheat had been a staple crop until medieval times but today has the status of a minor crop. Along with increasing popularity of ecological farming, its cultivation has been spreading in many areas all over Europe: Belgium, Germany, Switzerland, Austria, Poland, northern Italy, Slovakia, Czech Republic and Hungary [1-3]. Although being a major wheat growing area in Serbia known as "the breadbasket" of the Pannonian plain, in the Vojvodina Province, cultivation of spelt has no tradition. But, spelt wheat has recently become attractive for organic farmers. However, little is known

Correspondence: B. Filipčev, University of Novi Sad, Institute of Food Technology, Bulevar cara Lazara 1, 21000 Novi Sad, Serbia.

E-mail: bojana.filipcev@fins.uns.ac.rs

Paper received: 6 June, 2012

Paper accepted: 17 July, 2012 about spelt varieties available for cultivation in Vojvodina as well as their adaptation, performance and technological features under our environmental conditions.

Spelt wheat is a hexaploid hulled sub-species of common wheat. Spelt possesses many similar features to common wheat but also many significant distinctions regarding genetic, agricultural, physicochemical and nutritional characteristics. There is abundant information on the genetic diversity [4], bread-making performance [5] and nutritional value of spelt wheat [6-8]. Spelt is usually perceived as "healthier" and more "natural" than common wheat. It has been claimed to be more nutritious than common wheat and better tolerated by celiac patients and those with wheat allergy but these claims have been little substantiated by univocal scientific data [6,9-13]. Furthermore, spelt has been promoted as having therapeutic health benefits in the treatments of colitis ulcerosa, neurodermitis, depression and high blood cholesterol [14-16]. Agriculturally, spelt has advantages over common wheat as it is more resistant to harsh environmental conditions and can grow without the use of pesticides and fertilization [17]. However, it is susceptible to lodging and has lower yields than modern wheat. Furthermore, spelt is covered with a tough husk, which requires additional removal before milling the grain into flour. In contrast to the advantages regarding some agricultural 
and nutritional features, the dough quality and breadmaking ability of spelt has been described as poor compared to common wheat. Although having higher gluten quantities, the quality of spelt gluten is inferior to that of modern wheat giving soft, less elastic, sticky and less stable dough $[5,18]$. Breads made from spelt wheat are characterized with lower volume and impaired crumb texture attributes [19] but are often described to have a highly appealing "nutty" flavour with good keeping qualities. High divergence in gluten quality was found among spelt cultivars, which made it possible to divide them into three quality groups regarding bread-making performance $[5,20]$ : 1) group of those similar to modern bread wheat; 2) group of typical spelt; 3) group of low quality cultivars. Overall, in bread-making, spelt requires some changes in the technological process: higher doses of ascorbic acid, shorter mixing times, and longer dough rest times with frequent rounding are commonly suggested [21].

The present study was undertaken to examine the technological and bread-making quality of three spelt varieties available for organic wheat producers in Serbia. In extended baking tests, the responses of each spelt genotype to the addition of various dough strengthening improvers (ascorbic acid, transglutaminase and glucose oxidase) were evaluated.

\section{MATERIALS AND METHODS}

\section{Materials}

Spelt wheat material was obtained from the Jevtic organic farm (Bačko Gradište, Serbia). Three spelt varieties (one unknown originating from Austria (Genotype 1); var. Eko-10 from Hungary (Genotype 2); and var. Nirvana from Serbia (Genotype 3)) were grown in 2010 and 2011 under ecological conditions. Spelt wheat was dehulled in a dehuller (Heger type DS I 400S, Herrensberg D-7033, Germany). Refined spelt wheat flour was produced by roll milling on a farm-scale mill (A 500 MSM KOMBI Getreide Mühle, Osttiroler Getreidemühlen, Stribach-Dölsach A-9991, Austria). The moisture content of the flours was between 10.60 and $10.82 \%$ and the ash content between 1.36 and $1.52 \%$ in dry matter (d.m.).

The L-ascorbic acid was purchased from BASF, Germany. Glucose oxidase (VERON ${ }^{\circledR}$ Oxibake) and transglutaminase (VERON ${ }^{\circledR}$ TG $100 \mathrm{U} / \mathrm{g}$ ) were obtained from $A B$ Enzymes (ABF Ingredients, Darmstadt, Germany).

\section{Methods}

\section{Flour analyses}

Protein content $(\mathrm{N} \times 5.7)$, wet gluten content and gluten index were determined according to ICC standard No. 105-2, 106-2 and 155. Rheological properties were determined on a Brabender farinograph and Cho- pin alveograph using standard procedures (ICC methods No. 115-1 and 121).

\section{SDS-PAGE analysis}

Sodium dodecyl sulfate polyacrylamide gel electrophoresis (SDS-PAGE) on $10 \%$ gel, in Tris-glycine buffer $(\mathrm{pH} 8.3)$ was used for the analyses [22]. Total reduced seed proteins were separated in order to define HMW GS composition. The gels were stained with Coomasie Brilliant Blue G-250, according to Neuhoff et al. [23].

\section{Baking tests}

Baking tests for tin bread were performed using a formulation and procedure that was constant for every flour except water addition. The standard recipe comprised flour (700 g), yeast (17.5 g), salt (14.0 g) and water according to farinograph absorption. In extended baking tests, response to dough strengthening improvers: ascorbic acid (ASC), transglutaminase (TG) and glucose oxidase (GOx) was estimated and the tested improvers were included in the mixing stage. ASC was added at dose $200 \mathrm{mg} / \mathrm{kg}$ flour, TG at $1.5 \mathrm{U} / \mathrm{g}$ flour and $\mathrm{GOx}$ at $100 \mathrm{mg} / \mathrm{kg}$ flour.

The baking trial for spelt wheat was modified in comparison to standard procedure. It was necessary to introduce shorter mixing time and longer duration of dough ripening at lower temperature with frequent rounding. The ingredients were mixed for 5 minutes and the dough was left for ripening (60 min) at $25{ }^{\circ} \mathrm{C}$ with rounding every $20 \mathrm{~min}$. Then, the dough was divided into $300 \mathrm{~g}$ portions, manually rounded, rolled and put into tin pans $(24.5 \mathrm{~cm} \times 9 \mathrm{~cm} \times 6.5 \mathrm{~cm})$. The final fermentation lasted $46 \mathrm{~min}$ for Genotype 1, $38 \mathrm{~min}$ for Genotype 2 and $43 \mathrm{~min}$ for Genotype 3. The breads were baked at $230^{\circ} \mathrm{C}$ for $20 \mathrm{~min}$ in a deck type oven.

\section{Bread quality evaluation}

Bread loaf volumes were determined by millet seed displacement. Specific volume, bread yield and volume yield were calculated using the equations (1)-(4).

$V_{\text {sp }}=V_{\text {bread }} / W_{\text {bread }}$

$B Y=\left(W_{\text {bread }} / W_{\text {dough }}\right) D Y$

$D Y=100\left(W_{\text {ingr }} / W_{\text {flour }}\right)$

$V Y=\left(V_{\text {bread }} / W_{\text {bread }}\right) B Y$

where $V_{\text {sp }}$ is specific volume $(\mathrm{ml} / \mathrm{g}) ; V_{\text {bread }}$ is bread loaf volume $(\mathrm{ml}) ; W_{\text {bread }}$ is bread loaf weight $(\mathrm{g}) ; B Y$ is bread yield $(\mathrm{g}) ; W_{\text {dough }}$ is dough piece weight $(\mathrm{g}) ; D Y$ is dough yield; $W_{\text {ingr }}$ is the sum of ingredient weights $(\mathrm{g}) ; W_{\text {flour }}$ is the weight of flour for mixing and dusting (g); $V Y$ is volume yield $\left(\mathrm{cm}^{3}\right)$.

The firmness and resilience of bread crumb were instrumentally recorded on a texture analyzer TA.XTplus (Stable Micro Systems, England, UK) equipped with a $36 \mathrm{~mm}$ cylindrical probe according to AACC method 7410A, modified as described in Filipčev et al. [24]. Crumb 
colour properties were measured with a Chroma meter (CR-400/410, Konica, Minolta, Japan), which was calibrated against white calibration standard (CM $-\mathrm{A} 70) . L^{*}$, $a^{*}$ and $b^{*}$ values and hue angle $\left(h^{*}\right)$ and difference in chroma $\left(C^{*}\right)$ were reported.

The sensory properties included the crumb elasticity and appearance of crumb pores (structure and uniformity, Dallman pores). Twenty four hours post baking, the breads were sliced and evaluated on a 5 point intensity scale by a 6-member panel which members are trained in sensory evaluation. The degrees of intensity were for pore structure ( $1=$ coarse; 2 = slightly coarse; 3 = fine; 4 = spongy; 5 = wooly), for pore uniformity ( 1 = non-uniform; 2 = slightly non-uniform; 3 = enough uniform; 4 = almost uniform; 5 = uniform), crumb elasticity ( 1 = non-acceptable; 2 = satisfactory; 3 = good; 4 = very good; 5 = excellent).

\section{Statistical analysis}

The experimental data were analyzed by two-way analysis of variance with first-order interactions using Tukey's test for mean differentiation. Statistica 7.1 statistical software (StatSoft Inc., Tulsa, Oklahoma) was used. Results shown are mean values of at least three measurements. Instrumental texture parameters were derived from 12 measurements per each sample.

\section{RESULTS AND DISCUSSION}

\section{Protein and gluten content}

There was a significant effect of year and variety by year interaction $(p<0.001)$ as well as variety $(p<0.05)$ on the protein content of spelt flour. In all three spelt varieties, the protein content in the second year was significantly lower than in the first year. In the first year, the average protein content was $16.08 \% \mathrm{~d} . \mathrm{m}$. with the highest $17.02 \%$ d.m. registered in Genotype 3 whereas in the second year the average proteins dropped to $13.00 \%$ d.m. (Table 1). Similar variability of protein content in spelt wheat was observed in the study of Pasqualone et al. [25] from Italy. Some authors pointed out the high influence of environmental factors on proteins as well as on many other quality attributes of spelt wheat $[26,27]$. Spelt wheat is usually reported to have higher protein contents than common wheat but the values were usually found to vary over wide ranges. Abdel-Aal et al. reported $13.2-14.2 \%$ d.m. average proteins in soft spelt varieties [19]; Grela 10.71-14.38\% d.m. [7]; Škeř́ková et al. 18.1\% [28]; Skrabanja et al. 12.4-14.0\% d.m. [29]; Reiter et al. [21] summoned values to range between $15-19 \%$. Zieliński et al. [3] reported that the protein content of spelt flour

Table 1. Analysis of variance of selected quality traits for spelt varieties grown in two-year trials at one location; $A, B-U p p e r$ case letters are used to compare variations due to year. Different letters denote significant difference at $p<0.05$ (Tukey HSD); $a, b, c-D i f-$ ferent letters in a row denote significant difference at $p<0.05$ (Tukey HSD)

\begin{tabular}{|c|c|c|c|c|c|c|c|c|c|}
\hline \multirow{3}{*}{$\begin{array}{l}\text { Parameter } \\
\text { Protein, \% DM }\end{array}$} & \multicolumn{4}{|c|}{$p$-Value } & \multirow{2}{*}{\multicolumn{2}{|c|}{ Year }} & \multicolumn{3}{|c|}{ Spelt genotype } \\
\hline & \multirow{3}{*}{$\begin{array}{c}\text { ANOVA Model } \\
p<0.001\end{array}$} & \multirow{3}{*}{$\frac{\text { Year }}{p<0.001}$} & \multirow{3}{*}{$\begin{array}{l}\text { Genotype } \\
p=0.021\end{array}$} & \multirow{3}{*}{$\begin{array}{c}\text { Genotype } \times \text { Year } \\
p<0.001\end{array}$} & & & \multirow{2}{*}{$\frac{1}{15.81^{\mathrm{a}}}$} & \multirow{2}{*}{$\frac{2}{15.42^{\mathrm{a}}}$} & \multirow{2}{*}{$\frac{3}{17.02^{b}}$} \\
\hline & & & & & 2010 & $16.08^{B}$ & & & \\
\hline & & & & & 2011 & $13.00^{\mathrm{A}}$ & $12.77^{\mathrm{a}}$ & $13.87^{b}$ & $12.37^{\mathrm{a}}$ \\
\hline \multirow[t]{2}{*}{ Wet gluten, \% } & $p<0.001$ & $p<0.001$ & $p<0.001$ & $p<0.001$ & 2010 & $42.43^{B}$ & $40.80^{\mathrm{a}}$ & $41.90^{\mathrm{a}, \mathrm{b}}$ & $44.60^{b, c}$ \\
\hline & & & & & 2011 & $39.22^{\mathrm{A}}$ & $37.05^{a}$ & $46.30^{b}$ & $34.30^{\mathrm{a}}$ \\
\hline \multirow[t]{2}{*}{ Gluten index, \% } & $p<0.001$ & $p=0.002$ & $p<0.001$ & $p<0.001$ & 2010 & $76.00^{\mathrm{B}}$ & $92.00^{c}$ & $54.00^{\mathrm{a}}$ & $82.00^{b}$ \\
\hline & & & & & 2011 & $72.50^{\mathrm{A}}$ & $86.50^{\mathrm{b}}$ & $36.50^{\mathrm{a}}$ & $94.50^{c}$ \\
\hline \multirow[t]{2}{*}{ Absorption, \% } & $p<0.001$ & $p<0.001$ & $p<0.001$ & $p=0.044$ & 2010 & $56.70^{A}$ & $55.20^{\mathrm{a}}$ & $59.30^{\mathrm{b}}$ & $55.60^{\mathrm{a}}$ \\
\hline & & & & & 2011 & $59.22^{\mathrm{B}}$ & $58.05^{a}$ & $61.95^{\mathrm{b}}$ & $57.65^{\mathrm{a}}$ \\
\hline \multirow[t]{2}{*}{ Dough stability } & $p<0.001$ & $p=$ & $p<0.001$ & $p<0.001$ & 2010 & $1.00^{B}$ & $1.50^{\mathrm{C}}$ & $0.50^{\mathrm{a}}$ & $1.00^{b}$ \\
\hline & & 0.0014 & & & 2011 & $0.67^{A}$ & $0.75^{b}$ & $0.00^{\mathrm{a}}$ & $1.20^{\mathrm{c}}$ \\
\hline \multirow[t]{2}{*}{ Dough weakening } & $p<0.001$ & $p<0.001$ & $p<0.001$ & $p<0.001$ & 2010 & $120.00^{B}$ & $80.00^{a}$ & $195.00^{b}$ & $85.00^{\mathrm{a}}$ \\
\hline & & & & & 2011 & $88.33^{A}$ & $77.50^{b}$ & $130.00^{c}$ & $57.50^{\mathrm{a}}$ \\
\hline \multirow[t]{2}{*}{$W / 10^{-4} \mathrm{~J}$} & $p<0.001$ & $p<0.001$ & $p<0.001$ & $p<0.001$ & 2010 & $65.67^{B}$ & $113.00^{c}$ & $26.00^{\mathrm{a}}$ & $58.00^{b}$ \\
\hline & & & & & 2011 & $51.17^{A}$ & $46.00^{b}$ & $34.00^{\mathrm{a}}$ & $73.50^{c}$ \\
\hline \multirow[t]{2}{*}{$P / \mathrm{mm} \mathrm{H}_{2} \mathrm{O}$} & $p<0.001$ & $p<0.001$ & $p<0.001$ & $p<0.001$ & 2010 & $32.33^{B}$ & $38.00^{b}$ & $29.00^{\mathrm{a}}$ & $30.00^{\mathrm{a}}$ \\
\hline & & & & & 2011 & $28.33^{A}$ & $26.00^{\mathrm{a}}$ & $27.50^{\mathrm{a}}$ & $31.50^{b}$ \\
\hline \multirow[t]{2}{*}{$L / \mathrm{mm}$} & $p<0.001$ & $p=0.069$ & $p<0.001$ & $p=0.003$ & 2010 & $111.67^{\mathrm{A}}$ & $144.00^{b}$ & $45.00^{\mathrm{a}}$ & $146.00^{b}$ \\
\hline & & & & & 2011 & $116.83^{A}$ & $144.00^{b}$ & $66.00^{\mathrm{a}}$ & $140.50^{b}$ \\
\hline \multirow[t]{2}{*}{$P / L$} & $p<0.001$ & $p=0.001$ & $p<0.001$ & $p=0.005$ & 2010 & $0.35^{B}$ & $0.26^{\mathrm{a}}$ & $0.60^{b}$ & $0.21^{\mathrm{a}}$ \\
\hline & & & & & 2011 & $0.27^{A}$ & $0.18^{\mathrm{a}}$ & $0.415^{\mathrm{b}}$ & $0.23^{\mathrm{a}}$ \\
\hline \multirow[t]{2}{*}{$G$} & $p<0.001$ & $p=0.007$ & $p<0.001$ & $p<0.001$ & 2010 & $22.83^{\mathrm{A}}$ & $26.70^{b}$ & $14.90^{\mathrm{a}}$ & $26.90^{\mathrm{b}}$ \\
\hline & & & & & 2011 & $23.72^{\mathrm{B}}$ & $26.70^{b}$ & $18.10^{\mathrm{a}}$ & $26.35^{\mathrm{b}}$ \\
\hline
\end{tabular}


with extraction rate of $65-70 \%$ ranged from 7.50 to $10.80 \%$.

All spelt varieties showed high wet gluten contents, in average approximately $40 \%$, which is considered appropriate for baking applications. Gluten index showed wide variations among cultivars, in the first year it ranged from $92 \%$ (Genotype 1) to $54 \%$ (Genotype 2) whereas in the second year it was $94.50 \%$ (Genotype 3)-36.50\% (Genotype 2) (Table 1). Both parameters showed significant effect of year, genotype and genotype $\mathrm{x}$ year interaction at $(p<0.001)$ except for the gluten index, where the effect of year was significant $(p<0.01)$. A similar range of gluten index $(41-82)$ and somewhat lower wet gluten contents (below 40\%) were reported by Zielinsky et al. [3] for spelt hybrids bred in Poland. However, gluten index of 36.50 found in Genotype 2 is lower than expected and less commonly reported although Ceglińska [30] observed large heterogeneity in this parameter for 16 hybrids of spelt and wheat spanning from 6 to 82. Lacko-Bartošová and Rédlová [2] determined gluten index values in the range 43.57-64.67 for five spelt cultivars.

\section{Farinogram and alveograph assessments}

Doughs prepared from spelt flours exhibited moderate to poor rheological properties characterized with short dough stabilities (0.0-1.5 min) (Table 1). Water absorption of flours was within the range acceptable for baking (55.2-61.9\%). Siemianowska et al. [31] found higher water absorptions for spring spelt varieties (61.3-64.9\%). According to dough softening, two varieties (Genotype 1 and Genotype 3) accomplished the quality requirements of medium quality bread wheats whereas Genotype 3 showed high dough softening as in low quality wheats. For the alveograph dough deformation energy $(\mathrm{W})$, values in the range $26 \times 10^{-4}-113 \times 10^{-4}$ $\mathrm{J}$ were recorded, which is below the minimal value $\left(130 \times 10^{-4} \mathrm{~J}\right)$ required for standard bread by French criteria [32]. Pasqualone et al. [25] reported higher $W$ values for spelt $c v$. Forenza, $122.6 \times 10^{-4}-145 \times 10^{-4} \mathrm{~J}$. The best performance regarding this parameter was shown by Genotype $1\left(113 \times 10^{-4} \mathrm{~J}\right)$ but it drastically declined in the subsequent year $\left(46 \times 10^{-4} \mathrm{~J}\right)$. Genotype 1 and 3 had $P / L$ ratio well below 0.6 whereas Genotype 3 showed higher values (0.6 in 2010 and 0.4 in 2011). $P / L$ Values below 0.6 are considered favourable for breadmaking. In contrast to Genotype 2, $P / L$ values of Genotype 1 and 2 were not affected by yearly environmental conditions. Index of swelling $(G)$ was over 20 for Genotype 1 and 3 , which meets the requirements for bread wheats (French standard) but below 20 for Genotype 2. Generally, all rheological parameters varied significantly according to year, genotype and genotype $x$ year interaction (at $p<0.001$ or $p<0.01$ levels) except alveograph $L$ value, which was not year dependent ( $p>$ 0.05).

\section{Bake tests}

All bread-making parameters were significantly affected by genotype, year and their interaction apart from bread yield, which was not cultivar dependent (Table 2). Bread yields ranged from 132.2 to $137.322 \mathrm{~g}$, which is a typical range for breadmaking. Specific volume of breads ranged from 2.34 to $3.24 \mathrm{ml} / \mathrm{g}$ and significantly declined in the second year of trial for Genotype 1 and 3 but increased for Genotype 2. However, the achieved volume yield of Genotype 2 was lower than those of other two genotypes showing its weaker performance regarding this parameter in this assessment. A similar range of specific volumes for breads made from spring spelt (below $3 \mathrm{ml} / \mathrm{g}$ ) was reported by Siemianowska et al. [31] while Pasqualone et al. [25] reported much higher values (3.64-3.75 ml/g) for spelt cultivar Forenza. Crumb firmness varied from 580.96 to $1757.85 \mathrm{~g}$. The softest crumb was exhibited by Genotype 1 during the first year but significantly worsened during the second year. Genotype 3 showed similar deterioration regarding this parameter whereas Genotype 2 improved crumb softness in the second year but all in all, it tended to have high values for crumb firmness. Breads with lower specific volume and firmer crumb had poorer pores with coarse structure.

Pearson correlation analysis of specific volume with rheological properties (Table 3 ) showed that it was strongly positively correlated $(p<0.01)$ with alveograph maximum overpressure, $P(0.90)$, and deformation energy $(W)$ (0.93). Crumb firmness was also strongly correlated with these parameters but negatively: $P$ $(-0.91)$ and $W(-0.92)$ at $p<0.01$. Crumb resilience was not significantly correlated to any of the traits. Crumb resilience measured instrumentally refers to the speed of crumb recovery after deformation whereas crumb elasticity determined by palpation estimates how well the product retains its original condition after it has been deformed and a degree to which the product springs back after a load is removed. Unlike crumb resilience, crumb elasticity showed high significant positive correlation with alveograph $P(0.95)$ and $W$ (0.99) $(p<0.01)$. This shows that the breadmaking potential of spelt varieties is mostly associated with dough strength and tenacity.

Gluten index, farinographic parameters, alveograph elasiticity $(L)$ and index of swelling $(G)$ also showed significant correlation (at $p<0.01$, i.e., $p<0.05$ ) with most bread characteristics except crumb resilience (Table 3). Better bread performance was associated with higher gluten index, higher dough stability, lower dough softening, higher dough extensibility and swellling. Interestingly, loaves with higher volume corresponded to doughs with lower water absorption indicating that, in spite of lower ability to absorb water to reach 500 B.U. consistency, gluten quality was ade- 
Table 2. Analysis of variance of quality attributes of bread made from spelt varieties grown in two-year trials at one location; A, $B$ Upper case letters are used to compare variations due to year. Different letters denote significant difference at $p<0.05$ (Tukey HSD); $a, b, c-$ Different letters in a row denote significant difference at $p<0.05$ (Tukey HSD)

\begin{tabular}{|c|c|c|c|c|c|c|c|c|c|}
\hline \multirow{2}{*}{ Parameter } & \multicolumn{4}{|c|}{$p$-Value } & \multirow{2}{*}{\multicolumn{2}{|c|}{ Year }} & \multicolumn{3}{|c|}{ Spelt cultivar } \\
\hline & ANOVA Model & Year & Cultivar & Cultivar $\mathrm{x}$ Year & & & Genotype 1 & Genotype 2 & Genotype 3 \\
\hline \multirow[t]{2}{*}{ Bread yield, \% } & $p<0.001$ & $p<0.00$ & $p=0.232$ & $p<0.001$ & 2010 & $133.95^{\mathrm{A}}$ & $136.00^{b}$ & $133.7^{a}$ & $132.15^{\mathrm{a}}$ \\
\hline & & & & & 2011 & $136.66^{\mathrm{B}}$ & $135.60^{a}$ & $137.05^{\mathrm{a}}$ & $137.32^{\mathrm{a}}$ \\
\hline \multirow[t]{2}{*}{ Volume yield, \% } & $p<0.001$ & $p<0.00$ & $p<0.001$ & $p<0.001$ & 2010 & $371.41^{B}$ & $441.340^{c}$ & $312.21^{a}$ & $360.67^{b}$ \\
\hline & & & & & 2011 & $342.44^{\mathrm{A}}$ & $333.81^{a, b}$ & $340.15^{b, c}$ & $353.36^{c}$ \\
\hline \multirow[t]{2}{*}{ Specific volume, $\mathrm{ml} / \mathrm{g}$} & $p<0.001$ & $p<0.00$ & $p<0.001$ & $p<0.001$ & 2010 & $2.77^{B}$ & $3.24^{c}$ & $2.34^{\mathrm{a}}$ & $2.73^{b}$ \\
\hline & & & & & 2011 & $2.50^{\mathrm{A}}$ & $2.46^{\mathrm{a}}$ & $2.48^{\mathrm{a}}$ & $2.57^{b}$ \\
\hline \multirow[t]{2}{*}{ Crumb firmness, $\mathrm{g}$} & $p<0.001$ & $p<0.00$ & $p<0.001$ & $p<0.001$ & 2010 & $1130.67^{A}$ & $580.96^{a}$ & $1757.85^{c}$ & $1053.18^{b}$ \\
\hline & & & & & 2011 & $1560.13^{B}$ & $1744.39^{c}$ & $1635.80^{b}$ & $1300.191^{a}$ \\
\hline \multirow[t]{2}{*}{ Crumb resilience, \% } & $p<0.001$ & $p<0.00$ & $p<0.001$ & $p<0.001$ & 2010 & $18.22^{A}$ & $22.40^{\mathrm{b}}$ & $15.89^{a}$ & $16.38^{a}$ \\
\hline & & & & & 2011 & $20.09^{B}$ & $17.07^{\mathrm{a}}$ & $24.62^{b}$ & $18.60^{a}$ \\
\hline \multirow[t]{2}{*}{ Crumb pore uniformity } & $p<0.001$ & $p<0.00$ & $p<0.001$ & $p<0.001$ & 2010 & $4.33^{\mathrm{A}}$ & $3.00^{\mathrm{a}}$ & $5.00^{b}$ & $5.00^{b}$ \\
\hline & & & & & 2011 & $3.33^{B}$ & $2.00^{\mathrm{a}}$ & $3.00^{b}$ & $5.00^{c}$ \\
\hline \multirow[t]{2}{*}{ Crumb pore structure } & $p<0.001$ & $p=0.00$ & $p<0.001$ & $p<0.001$ & 2010 & $2.00^{B}$ & $3.00^{c}$ & $1.00^{\mathrm{a}}$ & $2.00^{b}$ \\
\hline & & & & & 2011 & $1.80^{\mathrm{A}}$ & $1.8^{\mathrm{a}}$ & $1.8^{\mathrm{a}}$ & $1.8^{\mathrm{a}}$ \\
\hline \multirow[t]{2}{*}{ Crumb elasiticty } & $p<0.001$ & $p<0.00$ & $p<0.001$ & $p<0.001$ & 2010 & $1.75^{\mathrm{B}}$ & $2.75^{\mathrm{c}}$ & $1.00^{\mathrm{a}}$ & $1.50^{b}$ \\
\hline & & & & & 2011 & $1.40^{\mathrm{A}}$ & $1.20^{\mathrm{a}}$ & $1.20^{\mathrm{a}}$ & $1.80^{b}$ \\
\hline
\end{tabular}

Table 3. Pearson's coefficients of correlation among bread characteristics and other quality traits; * - significant at the level of 0.05 probability; ** - significant at 0.01 probability; ns not significant; Pro, protein content; WG, wet gluten content; GI, gluten index; Abs, farinograph water absorption; Sta, farinograph stability; DW, farinograph dough weakening; $P$, alveograph tenacity; $L$, alveograph extensibility; $P / L$, alveograph ratio; $G$, alveograph swelling; $W$, alveograph strength

\begin{tabular}{|c|c|c|c|c|c|c|c|c|c|c|c|}
\hline Parameter & Pro & WG & GI & Abs & Sta & DW & $\mathrm{P}$ & $\mathrm{L}$ & $\mathrm{P} / \mathrm{L}$ & G & W \\
\hline Specific volume & ns & ns & $0.52^{*}$ & $-0.72 * *$ & $0.73^{* *}$ & $-0.49^{*}$ & $0.90 * *$ & $0.57^{*}$ & ns & $0.57^{*}$ & $0.93^{* *}$ \\
\hline Crumb firmness & $-0.50 *$ & ns & $-0.57^{*}$ & $0.79 * *$ & $-0.79 * *$ & $0.51^{*}$ & $-0.91 * *$ & $-0.60 *$ & ns & $-0.59 *$ & $-0.92 * *$ \\
\hline Crumb resilience & ns & ns & ns & ns & ns & ns & ns & ns & ns & ns & ns \\
\hline Crumb elasticity & ns & ns & $0.61^{* *}$ & $-0.68 * *$ & $0.81^{* *}$ & $-0.55^{*}$ & $0.95^{* *}$ & $0.58^{*}$ & ns & $0.58^{*}$ & $0.99 * *$ \\
\hline Pore structure & ns & ns & $0.52 *$ & $-0.59 *$ & $0.63 * *$ & $-0.65 * *$ & $0.75 * *$ & $0.66 * *$ & $-0.60 *$ & $0.67 * *$ & $0.90 * *$ \\
\hline
\end{tabular}

quate enough to provide better bread-making performance (Table 3).

Earlier studies have shown that gluten with large strength (high $P$ values) in combination with extensible dough (high $L$ values) yields higher loaf volumes which was basically confirmed here, too. However, in the second year, Genotype 2, although showing similar $\mathrm{P}$ and much lower extensibility $L$ than Genotype 1 , gave bread with comparable volume to that of Genotype 1. This supports the suggestion given by Rao and co-workers [33] that in the case of weak gluten, extensible dough might not be so crucial for dough expansion during proofing and formation of high loaf volumes because the linkage between $P$ and $L$ is not perfect. According to Rao and co-workers [33], a proper balance of gluten strength $(P)$ and dough extensibility $(L)$ might be much more important for improved baking performance. However, in this accession, $P / L$ ratio showed significantly modest correlation with only one bread quality parameter, crumb pore structure $(-0.60)$.

\section{Extended bake tests with improvers}

In the extended bake tests, the response of spelt varieties to the addition of dough strengthening improvers such as ascorbic acid (ASC), glucose oxidase (GOx) and transglutaminase (TG) was evaluated. This was interesting because these improvers have different reaction mechanisms in dough. Ascorbic acid and GOx are oxidative agents whereas TG acts by direct protein crosslinking. Ascorbic acid does not act on the proteins directly and it has been hypothesized to be an intermediary in the oxidation processes in dough, blocking the effect of gluthatione, which results in the formation of disulfide cross-links between gluten proteins [34]. Glucose oxidase produces several effects in dough: 1) it catalyses the oxidation of $\beta$-D-glucose into gluconic acid in the presence of atmospheric oxygen; 2 ) it simultaneously transforms water into hydrogen peroxide which has been believed to act on - $\mathrm{SH}$ groups by formation of disulfide bonds leading to dough strength- 
ening [35]. GOx was also reported to have an ability to gelate water-soluble pentosans [36]. TG catalyses the reaction between the $\varepsilon$-amino group on protein-bound lysine residues and a $\gamma$ carboxamide group on proteinbound glutamine residue forming covalent cross-links due to "isopeptide" bonds ( $\varepsilon$ - $(\gamma-\mathrm{G} \ln )$-Lys bonds) causing the polymerization of proteins. As a result of higher proximity of sulphur containing amino acids, this activity may lead to spontaneous formation of disulfide bonds that additionally strengthen and stabilize dough [37]. The content of lysine is a limiting factor for isopeptide bond formations $[37,38]$. In spite of low lysine content, wheat gluten showed good reactivity to TG cross-linking action, which resulted in gels with improved structure and enhanced elasticity [39].

These improvers are frequently used in the treatments of weak and wheat bug damaged wheat. Ascorbic acid was shown to be an effective dough strengthener for low technological quality common wheat [40]. However, little data is available on the effect of dough strengtheners in spelt wheat. The action of translutaminase might be especially affected since different protein fractions have different susceptibilities to the cross-linking effect. It was found that in modern wheats, the most affected gluten fraction by TG reaction is the high molecular weight glutenin subunit (HMW-GS) [39]. The HMW-GS fractions of soft wheat were the most susceptible to the cross-linking effect of TG [41]. In comparison to common wheat, spelt has higher content of total gliadins and lower total glutenins. RP-HPLC analysis showed the predominance of $\alpha$-gliadins followed by $\gamma$ gliadins and low molecular weight glutenin subunits (LMW-GS) whereas $\omega$-gliadins and HMW-GS were minor in spelt [42]. It was revealed that in aestivum and durum wheat all gliadin subclasses $(\omega, \alpha+\beta, \gamma)$ participate in the cross-linking with the highest reactivity detected in the $\omega$ region [41]. Bauer et al. [43] concluded that HMW-GS subunits and $\alpha$-gliadins were mostly involved in the cross-linking action by TG in wheat.

The spelt varieties showed significant responses to the addition of improvers regarding specific volume and crumb firmness (Table 4 and Figure 1). These parameters significantly improved upon the treatments for all spelt varieties. The highest specific volume in all three spelt varieties was achieved by the action of ASC reaching values above $3 \mathrm{ml} / \mathrm{g}$. Crumb firmness was similarly affected; ASC treatment gave the softest crumb. The tested additives improved the bread shapes by increasing their heights and enhancing the formation of calotte. TG and ASC showed the highest effect on bread height. Crumb resilience was significantly increased by the addition of TG and ASC. With respect to crumb pore, TG and ASC provoked dense crumb structure with small pores, whereas GOx either produced no effect (in Genotypes 1 and 2) or gave a more porous crumb (in Genotype 3) (Figure 1). Similar crumb pore enlargement effect by GOx was reported by Pescador-Piedra et al. (2009) [44]. Regarding the response intensity of the majority of baking indicators to the tested dough strengthening improvers, it seems that the spelt genotypes followed the order: Genotype 3 > Genotype $1 \geq$ Genotype 2 . On the other hand, regarding their action and effect on baking quality indicators, the tested improvers followed the order: ascorbic acid $>$ transglutaminase $>$ glucose oxidase.

Breads from different spelt cultivars differed regarding crumb colour properties (Table 4). Genotype 3 provided the lightest and least colourful crumb with the lowest red and yellow tone. The addition of TG and ASC led to the formation of significantly lighter bread crumb in relation to control in all spelt varieties except in the case of bread from Genotype 2 with ascorbic acid which is probably a consequence of different light reflection due to formation of finer and smaller crumb pores. In comparison to the control, the addition of ASC significantly decreased the red tone in crumb except in Genotype 3 . There were no significant variations in other colour parameters of crumb due to addition of improvers.

\section{Electrophoretic analysis of HMW-GS alleles of spelt genotypes}

Many studies on common wheat have shown strong correlation between the baking performance and gluten quality [45]. Thus, the presented variability in baking performance of tested spelt wheat varieties and their response to the action of dough strengthening improvers should be due to the the viscoelastic properties of the gluten matrix, which is influenced by the qualitative and quantitative composition of glutenin and gliadin fractions. The composition of gluten is a varietal characteristic related to the allelic combination of genes coding for different subunits of glutenin and gliadin. A crucial factor for breadmaking quality is $\mathrm{HMW}$ glutenin, as well as LMW glutenin and gliadins [46].

The storage proteins of the spelt genotypes cultivated under ecological conditions were separated by SDS-PAGE electrophoresis to determine their HMW glutenin subunits. Five alleles at Glu-1 loci were determined: one allele at the Glu-A1, two at the Glu-B1, and two at the Glu-D1 locus. Table 5 presents the allelic composition of genes coding for the HMW glutenin subunits in the tested genotypes. The most abundant in the Glu-B1 was subunit $6+8$ coded by Glu-B1d allele. This subunit is commonly present in bread wheat and spelt and it was known as the preponderant subunit of spelt wheat $[47,48]$. The second allele Glu-B1bk coding for subunit pair 6.1+22.1 [49] occurred in one spelt genotype, Genotype 1. This allele was found in previous surveys of spelt wheat and its progenitors. The Glu-B1bk allele detected in European spelt was found 
Table 4. Response of spelt wheat flours to the addition of improvers with oxidizing or direct protein crosslinking action; $A, B, C-$ different upper case letters in a row indicate significant difference at $p<0.05$ (Tukey HSD); $a, b, c$-lower case letters are used to designate differences due to treatments within one genotype. Different letters indicate significant difference at $p<0.05$ (Tukey HSD); TG, transglutaminase (dose $1.5 \mathrm{U} / \mathrm{g}$ flour); GOx, glucose oxidase $(0.1 \mathrm{~g} / \mathrm{kg}$ flour); ASC, ascorbic acid (0.2 g/kg flour)

\begin{tabular}{|c|c|c|c|c|}
\hline Genotype & Treatments & Genotype 1 & Genotype 2 & Genotype 3 \\
\hline \multirow[t]{4}{*}{ Specific volume, ml/g } & Control & $2.64^{\mathrm{a} B}$ & $2.47^{\mathrm{a} A}$ & $2.71^{\mathrm{aB}}$ \\
\hline & TG & $2.79^{\mathrm{b} \mathrm{A}}$ & $2.79^{\mathrm{bA}}$ & $3.19^{\mathrm{CB}}$ \\
\hline & GOx & $2.79^{\mathrm{b} \mathrm{A}}$ & $2.89^{\mathrm{CB}}$ & $2.95^{\mathrm{bB}}$ \\
\hline & ASC & $3.24^{\mathrm{cA}}$ & $3.17^{\mathrm{dA}}$ & $3.43^{\mathrm{d} B}$ \\
\hline \multirow[t]{4}{*}{ Height, mm } & Control & $46.83^{\mathrm{aA}}$ & $45.00^{\mathrm{a} A}$ & $50.50^{\mathrm{a} B}$ \\
\hline & TG & $56.33^{\mathrm{bA}}$ & $53.50^{\mathrm{CA}}$ & $64.00^{\mathrm{b} \mathrm{B}}$ \\
\hline & GOx & $47.50^{\mathrm{a} \mathrm{A}}$ & $48.67^{\mathrm{b} A, \mathrm{~B}}$ & $52.67^{\mathrm{a} B}$ \\
\hline & ASC & $60.33^{\mathrm{bB}}$ & $52.33^{\mathrm{b}, \mathrm{c} \mathrm{A}}$ & $64.67^{b c}$ \\
\hline \multirow[t]{4}{*}{ Crumb firmness, g } & Control & $1488.42^{\mathrm{CB}}$ & $1678.35^{\mathrm{CB}}$ & $1112.75^{\mathrm{bA}}$ \\
\hline & TG & $1157.51^{\text {b B }}$ & $1197.42^{\mathrm{bB}}$ & $738.81^{\mathrm{aA}}$ \\
\hline & GOx & $1026.39^{\mathrm{b} B}$ & $876.77^{\mathrm{a} A, \mathrm{~B}}$ & $641.97^{\mathrm{a} A}$ \\
\hline & ASC & $604.78^{\mathrm{a} A}$ & $613.23^{\mathrm{aA}}$ & $480.06^{\mathrm{aA}}$ \\
\hline \multirow[t]{4}{*}{ Crumb resilience, \% } & Control & $17.34^{\mathrm{aA}}$ & $23.92^{\mathrm{a} B}$ & $19.07^{\mathrm{a} A}$ \\
\hline & TG & $28.56^{\mathrm{bA}}$ & $29.87^{b, c B}$ & $28.97^{\mathrm{cA}, \mathrm{B}}$ \\
\hline & GOx & $19.84^{\mathrm{a} A}$ & $27.05^{\mathrm{a}, \mathrm{b} B}$ & $24.42^{\mathrm{bB}}$ \\
\hline & ASC & $28.14^{\mathrm{b} A}$ & $32.63^{\mathrm{CB}}$ & $29.86^{\mathrm{CA}, \mathrm{B}}$ \\
\hline \multirow[t]{4}{*}{ Dallmann pores } & Control & 7 & 6 & 7 \\
\hline & TG & 8 & 8 & 8 \\
\hline & GOx & 7 & 5 & 7 \\
\hline & ASC & 8 & 5 & 8 \\
\hline \multicolumn{5}{|c|}{ Crumb colour parameters } \\
\hline \multirow[t]{4}{*}{$\overline{L^{*}}$} & Control & $59.92^{\mathrm{a} A, \mathrm{~B}}$ & $59.02^{\mathrm{aA}}$ & $63.53^{\mathrm{a} B}$ \\
\hline & TG & $64.04^{\mathrm{b} \mathrm{A}}$ & $63.73^{\mathrm{bA}}$ & $65.77^{\mathrm{aA}}$ \\
\hline & GOx & $60.90^{\mathrm{a}, \mathrm{b} \mathrm{A}}$ & $58.92^{\mathrm{aA}}$ & $64.98^{\mathrm{a} B}$ \\
\hline & ASC & $65.34^{\mathrm{CB}}$ & $60.18^{\mathrm{aA}}$ & $68.28^{\mathrm{bB}}$ \\
\hline \multirow[t]{4}{*}{$a^{*}$} & Control & $3.23^{\mathrm{bB}}$ & $4.29^{d c}$ & $2.31^{\mathrm{aA}}$ \\
\hline & TG & $3.02^{a, b ~ A ~}$ & $3.90^{c, d B}$ & $2.48^{\mathrm{aA}}$ \\
\hline & GOx & $2.60^{\mathrm{a}, \mathrm{b} A}$ & $3.78^{b, c, d B}$ & $2.24^{\mathrm{aA}}$ \\
\hline & ASC & $2.59^{\mathrm{aA}}$ & $3.54^{a, b, c B}$ & $2.16^{\mathrm{aA}}$ \\
\hline \multirow[t]{4}{*}{$b^{*}$} & Control & $21.33^{\mathrm{a} B}$ & $22.70^{\mathrm{a} B}$ & $19.54^{\mathrm{a} \mathrm{A}}$ \\
\hline & TG & $19.74^{\mathrm{aA}}$ & $22.27^{\mathrm{a} B}$ & $19.62^{\mathrm{aA}}$ \\
\hline & GOx & $19.78^{\mathrm{aA}}$ & $21.45^{a B}$ & $20.08^{\mathrm{aA}, \mathrm{B}}$ \\
\hline & ASC & $20.56^{\mathrm{aA}}$ & $21.94^{\mathrm{a} B}$ & $20.08^{\mathrm{aA}}$ \\
\hline \multirow[t]{4}{*}{$C^{*}$} & Control & $21.57^{\mathrm{a} B}$ & $23.10^{\mathrm{a} B}$ & $19.68^{\mathrm{a} A}$ \\
\hline & TG & $19.97^{\mathrm{a} A}$ & $22.60^{a B}$ & $19.78^{\mathrm{a} \mathrm{A}}$ \\
\hline & GOx & $19.95^{\mathrm{aA}}$ & $21.79^{\mathrm{aB}}$ & $20.20^{\mathrm{aA}}$ \\
\hline & ASC & $20.72^{\mathrm{a} B}$ & $22.22^{\mathrm{aA}}$ & $20.33^{\mathrm{a} A, \mathrm{~B}}$ \\
\hline \multirow[t]{4}{*}{$h^{*}$} & Control & $81.38^{\mathrm{a} B}$ & $79.31^{\mathrm{aA}}$ & $83.26^{a, b c}$ \\
\hline & TG & $81.31^{\mathrm{aA}}$ & $80.09^{a, b A}$ & $82.80^{\mathrm{a} B}$ \\
\hline & GOx & $82.51^{\mathrm{a}, \mathrm{b} B}$ & $80.01^{\mathrm{a}, \mathrm{b} \mathrm{A}}$ & $83.63^{\mathrm{a}, \mathrm{b} c}$ \\
\hline & ASC & $82.83^{b \mathrm{~B}}$ & $80.83^{\mathrm{bA}}$ & $83.90^{\mathrm{b} \mathrm{B}}$ \\
\hline
\end{tabular}

to occur simultaneously in cultivated emmer wheat whereas it did not appear in bread wheat [50]. Incidence of Glu-B1bk allele is quite different in spelt germoplasm of different origin. The frequency higher than $30 \%$ in samples from Central Europe was recorded by several authors [4,51]. Analysing 162 accessions from various countries. Pu and co-workers [48] found this HMW allele only in 1 accession originated from 


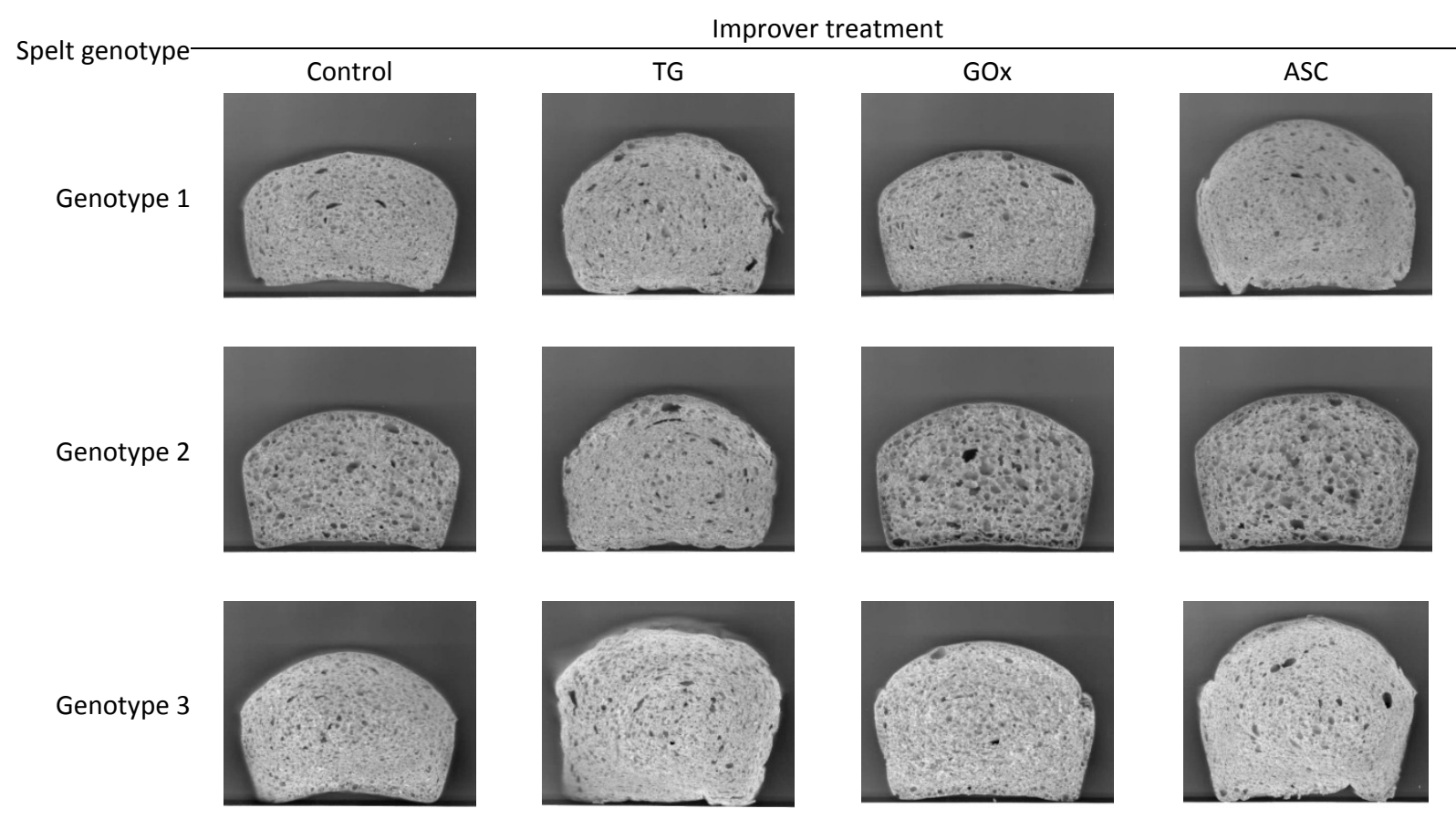

Figure 1. Effect of improvers on crumb structure of spelt breads; TG, transglutaminase (dose $1.5 \mathrm{U} / \mathrm{g}$ flour); GOx, glucose oxidase $(0.1 \mathrm{~g} / \mathrm{kg}$ flour); ASC, ascorbic acid ( $0.2 \mathrm{~g} / \mathrm{kg}$ flour).

Switzerland. At the Glu-D1 locus 5+10 and 2+12 HMW subunits were present (Table 5). Two spelt wheat accessions had the Glu-D1d allele (subunit 5+10). The subunit 2+12 (Glu-D1a), associated with poor quality, was only detected in one genotype, Genotype 2.

Table 5. Spelt varieties and the composition of HMW glutenin coding genes

\begin{tabular}{lccc}
\hline \multirow{2}{*}{ Genotype } & \multicolumn{3}{c}{ HMW glutenin subunit allelles composition } \\
\cline { 2 - 4 } & Glu-A1 & Glu-B1 & Glu-D1 \\
\hline Genotype 1 & Glu-A1a/1 & Glu-B1bk/6.1+22.1 & Glu-D1d/5+10 \\
Genotype 2 & Glu-A1a/1 & Glu-B1d/6+8 & Glu-D1a/2+12 \\
Genotype 3 & Glu-A1a/1 & Glu-B1d/6+8 & Glu-D1d /5+10 \\
\hline
\end{tabular}

It has been known that subunits denoted as GluA1 1 , GluD1 $5+10$ are related to high technological quality whereas allelic combination such as GluB1 $6+8$ and GluD1 2+12 are related to poor baking quality. Thus, the poor bread-making performance exerted by Genotype 2 is probably due to its weaker genetic potential whereas the other two genotypes are much more promising for use in breadmaking.

\section{CONCLUSION}

In spite of observing significant environmental influences on most parameters affecting dough rheological properties, it was possible to estimate the bread-making properties of spelt varieties grown under organic conditions in Serbia. Genotypes 1 and 3 showed moderate suitability for bread-making applications whereas
Genotype 2 had poor performance. These observations agreed with the genetic potential of these varieties as it was shown that the poorer performing variety was with the presence of gluten subunits $6+8$ and $2+12$ at loci Glu-B1 and Glu-D1, respectively which is particularly related to low bread-making potential. The majority of bread quality traits were significantly correlated to dough tenacity and strength (alveograph $P$ and $W$ values) showing that baking quality could be attributed mostly to gluten strength. It was also shown that the addition of dough strengthening improvers such as ascorbic acid, transglutaminase or glucose oxidase enhanced the specific volume, loaf height and appearance as well as crumb properties. The tested spelt varieties produced the highest responses to the addition of ascorbic acid. The variety with the best response to improvers was Genotype 3.

\section{Acknowledgement}

The authors would like to acknowledge the Ministry of Education, Science and Technological Development of the Republic of Serbia (Grant III 46005) for financial support to conduct the research and ABF Ingredients Company (Darmstadt, Germany) for kindly donating the samples of enzymes. Also, we would like to thank Srđan Šolaja from Barentz d.o.o. (Belgrade, Serbia) for his engagement in providing the enzyme samples.

\section{REFERENCES}

[1] A. Trocolli, P. Codianni, Appropriate seeding rate for einkorn, emmer, and spelt grown underrainfed con- 
dition in southern Italy, Eur. J. Agron. 22 (2005) 293-300 .

[2] M. Lacko-Bartošová, M. Rédlová, The significance of spelt wheat cultivated in ecological farming in the Slovak Republic, in: Proceeding of the Conference on Organic Farming 2007, Nitra, Slovakia, , 2007, pp. 79-81.

[3] H. Zieliński, A. Ceglińska, A. Michalska, Bioactive compounds in spelt bread, Eu. Food Res. Technol. 226 (2008) 537-544.

[4] X. An, L. Qiaoyun, Y. Yueming, X. Yinghua, S.L.K. Hsam, F.J. Zeller, Genetic diversity of European spelt wheat (Tritcium aestivum ssp. spelta L. em. Thell.) revealed by glutenin subunit variations at the Glu-1 and Glu-3 loci, Euphytica 146 (2005) 193-201.

[5] T.J. Schober, R.B. Scott, M. Kuhn, Gluten proteins from spelt (Triticum aestivum ssp. spelta) cultivars: a rheological and size-exlusion high-performance liquid chromatography study, J. Cereal Sci. 44 (2006) 161-173.

[6] E.S.M. Abdel-Aal, P. Hucl, F.W. Sosulski, Compositional and nutritional characteristics of spring einkorn and spelt wheats, Cereal Chem. 72 (1995) 621-624.

[7] E.R. Grela, Nutrient composition and content of antinutritional factors in spelt (Triticum spelta L) cultivars, J. Sci. Food Agr. 71 (1996) 399-404.

[8] M. Lacko-Bartošová, P. Otepka, Quantitative characters and chemical composition of spelt wheat cultivars grown in southern Slovakia. Acta Phytotech. Zootech. 4 (2001) 71-73.

[9] A. Bognar, C. Kellermann, Vergleichende Untersuchungen über den Gehalt an Vitaminen in Dinkel, Weizen und Roggen, Ernährungsforschung 38 (1993) 149-170.

[10] G.S. Ranhotra, J.A. Gelroth, B.K. Glaser, K.J. Lorenz, Baking and nutritional qualities of a spelt wheat sample, Lebensm. Wiss. U Technol. 28 (1995) 118-122.

[11] K.G. Campbell, Spelt: Agronomy, Genetics, and Breeding, in: J. Janick (Ed.), Plant Breeding Reviews, Bulletins and Technical Reports 15 (1997) 187-213.

[12] D.D. Kasarda, R. D'Ovidio, Deduced amino acid sequence of an $\alpha$-gliadin gene from spelt wheat (spelta) induces sequences active in celiac disease. Cereal Chem. 76 (1999) 548-551.

[13] T.J. Schober, Eigenschaften der Kleberproteine des technologischer Sicht, PhD thesis, University of Hohenheim, Stuttgart-Hohenheim, Germany, 2001.

[14] G. Hertzka, W. Strechlow, Handbuch der HildegardMedizin, Nr. 4. Der Dinkel als Heilmittel, Freiburg, Bauer Verlag, Germany, 1988.

[15] W. Strechlow, G. Hertzka, W. Wueffen, The dietary properties of spelt in the treatment of cronical diseases, in: Proceedings 2, Hohenheimer Dinkelkolloquium Verlag, Stuttgart, 1991, pp. 243-259.

[16] W. Strechlow, G. Hertzka, W. Weuffen, Aspetti nutrizionali, in: P.Perrino, D. Semeraro, G. Laghetti, (Eds.), Le caratteristiche dietetiche del faro, Un cereal della salute, Potenza, Italy, CNR, Bari,1994, pp. 52-66.

[17] G. Bonifácia, V. Galli, R. Francisci, V. Mait, V. Skrabanja, I. Kreft, Characteristics of spelt wheat products and nutritional valueof spelt wheat-based bread, Food Chem. 68 (2000) 437-441.

[18] A. Pruska-Kedzior, Z. Kedzior, E. Klockiewicz-Kaminska, Comparison of viscoelastic properties of gluten from spelt and common wheat, Eu. Food Res. Technol. 227 (2008) 199-207.

[19] E-S.M. Abdel-Aal, P. Hucl, F.W. Sosulski, P.R. Bhirud, Kernel, milling and baking properties of spring-type spelt and einkorn wheats. J. Cereal Sci. 261997 363$-370$.

[20] T.J. Schober, M. Kuhn, Capillary zone electrophoresis for gliadin separation: applications in a spelt breeding program. Eu. Food Res. Technol. 217 (2003) 350-359.

[21] E. Reiter, M. Werteker, L. Schmidt, E. Berghofer, Spelt wheats varieties: new aspects and technological properties, in: Ž. Ugarčić-Hardi (Ed.), Proceedings of the Second Croatian Congress of Cereal Technologists "Brašno-kruh'99", Opatija, Croatia, 1999, Grafika d.o.o., Osijek, 2000, pp. 10-15.

[22] Lj. Vapa, M. Savic, The HMW glutenin subunits composition of wheat varieties bred in Yugoslavia, in: T.E. Miller, R.M.D. Koebner (Eds.), Proceeding of the $7^{\text {th }}$ International Wheat Genetics Symposium, Cambridge, UK, 1988, pp 1019-1023.

[23] V. Neuhoff, N. Arold, D.Taube, W. Ehrhardt, Improved staining of proteins in polyacrilamide gels including isoelectric focusing gels with clear background at nanogram sensitivity using Coomasie Brilliant Blue G-250 and R-250, Electrophoresis 9 (1988) 255-262.

[24] B. Filipčev, Lj. Lević, M. Bodroža-Solarov, N. Mišljenović, G. Koprivica, Quality characteristics and antioxidant properties of breads supplemented with sugar beet molasses-based ingredients, Int. J Food Prop. 13 (2010) 1035-1053.

[25] A. Pasqualone, A.R. Piergiovanni, F. Caponio, V.M. Paradiso, C. Summo, R. Simeone, Evaluation of the technological characteristics and bread-making quality of alternative wheat cereals in comparison with common and durum wheat, Food Sci. Technol. Int. 17 (2011) 135$-138$.

[26] M. Lacko-Bartošová, J. Korczyk-Szabó, R. Ražný, Triticum spelta - a specialty grain for ecological farming systems, Res. J. Agr. Sci. 42 (2010) 143-147.

[27] H.F. Gomez-Becerra, H. Erdem, A. Yazici, Y. Tutus, B. Torun, L. Ozturk, I. Cakmak, Grain concentrations of protein and mineral nutrients in a large collection of spelt wheat grown under different environments, J. Cereal Sci. 52 (2010) 342-349.

[28] A. Škeříková, I. Capouchová, P. Konvalina, Z. Stehno, Technological quality of minor spring wheat species from organic farming and possibilities of their utilization, in: B. Šarapatka (Ed.), Proceedings of the $3^{\text {rd }}$ Scientific Conference, Prague, Czech Republic, Bioinstitute, Olomouc, 2011, pp 107-110.

[29] V. Skrabanja, B. Kovac, T. Golob, H.G.M. Liljeberg Elmstähl, I.M.E. Björk, I. Kreft, Effect of spelt wheat flour and kernel on bread composition and nutritional characteristics, J. Agr. Food Chem. 49 (2001) 497-500. 
[30] A. Ceglińska, Technological value of a spelt and common wheat hybrid, Electron. J. Polish Agr. Univ. 6 (2003) 1-6. (Available online http://www.ejpau.media.pl/issue1/ /food/art-02.html).

[31] E. Siemianowska, K.A. Skibniewska, M.F. Warechowska, M.F. Jędrzejczak, J. Tyburski, Flour and bread quality of spring spelt, World Acad. Sci. Eng. Technol. 59 (2011) 170-174.

[32] Lj. Đaković, Wheat flour-Physicochemical basis of determination of technological quality of wheat flour, Faculty of Technology, Novi Sad, 1997 (in Serbian).

[33] B.N. Rao, C.J. Pozniak, P.J. Hucl, C. Briggs, Baking quality of emmer-derived durum wheat breeding lines, J. Cereal Sci. 51 (2010) 299-304.

[34] C.E. Stauffer, Oxidants, in: C.E. Stauffer (Ed.), Functional additives for bakery foods, van Nostrand Rheinhold, New York, 1990, pp. 1-40.

[35] R. Hilhorst, B. Dunnewind, R. Orsel, P. Stegeman, T. van Vliet, H. Gruppen, H.A. Schols, Baking performance, rheology, and chemical composition of wheat dough and gluten affected by xylanase and oxidative enzymes, J. Food Sci. 64 (1999) 808-813.

[36] A.F. Dagdelen, D. Gocmen, Effects of glucose oxidase, hemicellulase and ascorbic acid on dough and bread quality, J. Food Quality 30 (2007) 1009-1022.

[37] H.S. Gurjal, C.M. Rosell, Functionality of rice flour modified with a microbial transglutaminase, J. Cereal Sci. 39 (2004) 225-230.

[38] E. Huang, L. Li, F. Wang, J. Wan, M.Tilley, C. Ren, S. Wu, Effects of transglutaminase on the rheological and Mixolab thermomechanical characteristics of oat dough, Food Chem. 121 (2010) 934-939.

[39] M. Dube, C. Schäfer, S. Neidhart, N. Carle, Texturisation and modification of vegetable proteins for food applications using microbial transglutaminase, Eu. Food Res. Technol. 225 (2007) 287-299.

[40] O. Šimurina, B. Filipčev, P. Jovanov, B. Ikonić, D. SimovićŠoronja, Analysis of the influence and optimization of concentration of organic acids on chemical and physical properties of wheat dough using a response surface methodology and desirability function, Hem. Ind., 2012, DOI: 10.2298/HEMIND1203020395.

[41] C.L. Medina-Rodríguez, P. Torres, F. Martínes-Bustos, B. Ramirez-Wong, O. Paredes-López, E. Castaño-Tostado, Effect of microbial transglutaminase on dough proteins of hard and soft (Triticum aestivum) and durum (Triticum durum) wheat cultivars. Cereal Chem. 86 (2009) 127-132.

[42] H. Wiser, Comparative investigations of gluten proteins from different wheat species. I. Qualitative and quantitative compositions of gluten protein types, Eu. Food Res. Technol. 211 (2000) 262-268.

[43] N. Bauer, P. Koehler, H. Wieser, P. Schieberle, Studies on effects of microbial transglutaminase on gluten proteins of wheat. I. Biochemical analysis, Cereal Chem. 80 (2003) 781-786.

[44] J.C. Peskador-Piedra, A. Garrido-Castro, J. ChanonaPérez, R. Farrera-Rebollo, G. Gutiérrez-López, G. Calderón-Domínguez, Effect of the addition of mixture of glucose oxidase, peroxidise and xylanase on rheological and breadmaking properties of wheat flour, Int. J. Food Prop. 12 (2009) 748-765.

[45] H. Wieser, W. Bushuk, F. MacRitchie, Gluten: A Balance of Gliadin and Glutenin, in: C. Wrigley, F. Bekes, W. Bushuk (Eds.), Gliadin and glutenin-the unique balance of wheat quality, AACC International,St. Paul, 2006, pp. 213-240.

[46] P.R. Shewry, A.S. Tatham, F. Barro, P. Barcelo, P. Lazzeri, Biotechnology of breadmaking: inraveling and manipulating the multi-protein gluten complex, Biotechnol. 13 (1995) 1185-1190.

[47] Z. Ni, Q. Sun, Y. Zhang, G. Liu, High molecular weight glutenin subunits composition of spelt wheat, J. Agr. Biotechnol. 10 (2002) 108-112.

[48] Z-E. Pu, Y-M. Wei, Y-L. Zheng, Genetic Variations of Gliadin and HMW Glutenin Subunits in Spelt Wheat, Ital. J. Agron. / Riv. Agron. 1 (2007) 41-46.

[49] R.A. Mclntosh, Y. Yamazaki, J. Dubcovsky, J. Rogers, C. Morris, D.J. Somers, R. Appels, K.M. Devos, Catalogue of Gene Symbols for Wheat, 2008.

[50] Y.Yan, S.L. Hsam, K.J. Yu, Z.Y. Jiang, I. Ohtsuka, F.J. Zeller, HMW and LMW glutenin alleles among putative tetraploid and hexaploid European spelt wheat (Triticum spelta L.) progenitors, Theor Appl. Genet. 107 (2003) 1321-1330.

[51] Y. Yan, Y. Jiang, M. Sun, J. Yu, Y. Xiao, J. Zheng, Y. Hu, M. Cai, Y. Li, S.L.K. Hsam, F.J. Zeller, Rapid identification of HMW glutenin subunits from different hexaploid wheat species by acidic capillary electrophoresis. Cereal Chem. 81 (2004) 561-566. 


\section{IZVOD}

\section{UPOREĐIVANJE PECIVNIH SVOJSTAVA I EFEKATA PRIMENE DODATAKA ZA JAČANJE TESTA KOD SORTI SPELTA PŠENICE GAJENIH U USLOVIMA ORGANSKE PROIZVODNJE U SEVERNOJ SRBIJI}

Bojana Filipčev ${ }^{1}$, Olivera Šimurina ${ }^{1}$, Marija Bodroža-Solarov ${ }^{1}$, Dragana Obreht ${ }^{2}$

${ }^{1}$ Univerzitet u Novom Sadu, Naučni institute za prehrambene tehnologije, Novi Sad, Srbija

${ }^{2}$ Univerzitet u Novom Sadu, Prirodno-matematički fakultet, Departman za biologiju i ekologiju, Novi Sad, Srbija

(Naučni rad)

Kod sorti spelta pšenice gajenih 2010. i 2011. godine ispitivana su reološka svojtva testa, pecivost i sastav alela gena koji kodiraju formiranje podjedinica glutenina visoke molekulske mase (HMW-GS) s ciljem određivanja njihovog potencijala pecivosti i pogodnosti za gajenje u uslovima organske proizvodnje. Rezultati ukazuju da ispitivani genotipovi imaju visok sadržaj proteina i vlažnog glutena ali i da postoje velike razlike u gluten indeksu zbog čega su ispitivani genotipovi produkovali testa osrednjih i slabih reoloških svojstava sa kratkim stabilitetima. Hlebovi od ispitivanih sorti spelte su imali tipičan prinos hleba, niske specifične zapremine i pokazali su velike razlike u čvrstoći sredine. Pokazana je značajna zavisnost između parametara pecivosti i jačine odnosno žilavosti testa. Većina ispitivanih svojstava je pokazala značajnu varijabilnost pod uticajem genotipova, godina i njihove interakcije. Genotipovi 1 i 3 su pokazali osrednji potencijal za primenu u pekarskoj industriji dok je genotip 2 pokazao slab potencijal što je u skladu sa njihovim genetskim potencijalom određenim preko sastava alela. Primenjeni ojačivači testa (askorbinska kiselina, transglutaminaza, glukoza oksidaza) pokazali su najveći efekat kod genotipa 3. Kod svih ispitivanih genotipova, najveći efekat je pokazala askorbinska kiselina.
Ključne reči: spelt • Reologija testa • Proizvodnja hleba • Asorbinska kiselina • Transglutaminaza • Glukoza oksidaza 